\title{
Formation mechanisms and sequence response of authigenic grain-coating chlorite: evidence from the Upper Triassic Xujiahe Formation in the southern Sichuan Basin, China
}

\author{
Yu Yu ${ }^{1,2} \cdot$ Liang-Biao $\operatorname{Lin}^{1,2} \cdot$ Jian Gao ${ }^{1,2}$
}

Received: 15 December 2015/Published online: 7 November 2016

(C) The Author(s) 2016. This article is published with open access at Springerlink.com

\begin{abstract}
Authigenic grain-coating chlorite is widely distributed in the clastic rocks of many sedimentary basins around the world. These iron minerals were mainly derived from flocculent precipitates formed when rivers flow into the ocean, especially in deltaic environments with high hydrodynamic conditions. At the same time, sandstone sequences with grain-coating chlorites also tend to have relatively high glauconite and pyrite content. EPMA composition analysis shows that glauconites with "high Al and low Fe" content indicate slightly to semi-saline marine environments with weak alkaline and weakly reducing conditions. By analyzing the chlorite-containing sandstone bodies of the southern Sichuan Xujiahe Formation, this study found that chlorite was mainly distributed in sedimentary microfacies, including underwater distributary channels, distributary channels, shallow lake sandstone dams, and mouth bars. Chlorite had a tendency to form in the upper parts of sandstone bodies with signs of increased base level, representing the influence of marine (lacustrine) transgression. This is believed to be influenced by megamonsoons in the Middle and Upper Yangtze Region during the Late Triassic Epoch. During periods of abundant precipitation, river discharges increased and more $\mathrm{Fe}$ particulates flowed into the ocean (lake). In the meantime, increases or decreases in lake level were only affected by
\end{abstract}

Liang-Biao Lin

linliangbiao08@cdut.cn

1 State Key Laboratory of Oil and Gas Reservoir Geology and Exploitation, Chengdu University of Technology, Chengdu 610059, Sichuan, China

2 Institute of Sedimentary Geology, Chengdu University of Technology, Chengdu 610059, Sichuan, China

Edited by Jie Hao precipitation for short periods of time. The sedimentary environment shifted from weakly oxidizing to weak alkaline, weakly reducing conditions as sea level increased, and Fe-rich minerals as authigenic chlorite and glauconite began to form and deposit.

Keywords Sichuan Basin · Xujiahe Formation · Graincoating chlorite · Glauconite · Pyrite

\section{Introduction}

Grain-coating chlorite, also known as pore-lining chlorite, is widely distributed in many sedimentary basins around the world. Studies have been performed on many sedimentary formations such as the Upper Triassic Yanchang Formation in the Ordos Basin (Zhang et al. 2011; Ding et al. 2013; Zhang et al. 2013; Zhu et al. 2015), the Upper Jurassic in the Songliao Basin (Zeng 1996), Xujiahe Formation in the Sichuan Basin (Liu et al. 2009; Huang et al. 2010; Zou et al. 2013), Middle Jurassic Shaximiao Formation in the Sichuan Basin (Lü et al. 2015), Jurassic Sangonghe Formation in the Junggar Basin (Xi et al. 2015), Upper Cretaceous in the Santos Basin, Brazil (Bahlis and Luiz 2013), and the Lower Vicksburg Formation in Southern Texas (Grigsby 2001). However, the clastic sequences which developed grain-coating chlorite in these sedimentary basins have varying characteristics. For example, the Yanchang Formation in the Ordos Basin was deposited in a continental sedimentary environment, the Upper Jurassic of the Songliao Basin is from a marine sedimentary environment, and the Xujiahe Formation in the Sichuan Basin is in a hybrid marine-continental sedimentary environment. However, all of these sandstones were deposited in high salinity environments. Huang et al. 
(2004) also thought chlorite formed in slightly saline water or semi-saline marine environments and characterized by successive ocean fluids.

Many studies performed on grain-coating chlorite mainly focus on the genetic mechanism of chlorite and its effects on reservoir porosity preservation. Bloch et al. (2002), Huang et al. (2004), and Zhu et al. (2004) thought grain-coating chlorite was beneficial to reservoir porosity preservation. Grain-coating chlorite which formed during the early diagenetic stage could enhance compaction resistance and inhibit quartz overgrowth cementation. Quartz overgrowths are considered one of the key factors responsible for reservoir densification (Zhu et al. 2009; Gu et al. 2014). However, Liu et al. (1998) believed primary porosity was reduced because of grain-coating chlorite which would block pore throats and reduce permeability. As for the study of chlorite (mainly referring to chlorite which precipitates from pore waters and forms early in diagenesis), study of the genetic mechanism got relatively consistent results. Grain-coating chlorite formation was thought to be mainly controlled by sedimentary facies and formed in high hydrodynamic conditions and weak alkaline environments with abundant $\mathrm{Fe}$ and $\mathrm{Al}$ sources (Huang et al. 2004). Sandstone sequences with well-developed chlorite were found in sedimentary facies conditions described above, including underwater distributary channels and distributary channels (Ehrenberg 1993; Pen et al. 2009; Okwese et al. 2012; Sun et al. 2014). However, there is no clear answer to why authigenic grain-coating chlorite tends to form in such conditions. Is there any connection between chlorite and the sedimentary environment conditions? What factors control the distribution and development of chlorite besides the sedimentary facies? Solving these problems would not only enhance the scientific understanding of authigenic grain-coating chlorite, but also provide data to search for sandstone sequences containing authigenic grain-coating chlorite.

Authigenic chlorite is widely distributed in Xujiahe Formation sandstones. Chlorite can be found in the main reservoir intervals (Xu 2 Member, Xu 4 Member, $\mathrm{Xu} 6$ Member). The majority of authigenic chlorite in the Xujiahe sandstones is found as grain coatings. This study examines samples from the Upper Triassic Xujiahe Formation sandstones taken from the southern Sichuan Basin. The study analyzes the occurrence and microcharacteristics of grain-coating chlorite through thin section, SEM, and EPMA analysis. The study also examines the characteristics of paragenetic minerals (glauconite, pyrite) and the vertical distribution patterns of authigenic chlorite in various sandstone bodies to study the formation environment, genetic mechanism, and other factors which affected the distribution of authigenic grain-coating chlorite.

\section{Geological setting}

Petroleum and gas exploration in the southern Sichuan Basin began in the 1950s, but the Upper Triassic Xujiahe Formation had not been widely explored until recently. In recent years, exploration of Danfengchang and Guanyinchang (which had seven industrial gas wells drilled by the end of 2013 with a cumulative gas production of $1.63 \times 10^{8} \mathrm{~m}^{3}$ ) had discovered a batch of commercial gas reservoirs (Zhu et al. 2014; Zhang et al. 2014). These discoveries show the Xujiahe Formation has excellent hydrocarbon potential.

The southern Sichuan Basin can be divided into the western, central, southwestern, and southeastern Sichuan low and steep structural areas (Lin et al. 2015). The Upper Triassic was the key period for Sichuan Basin sedimentary development, where the basin experienced transformation from a marine to a continental sedimentary environment (Lin et al. 2006) as marine facies to transitional facies to continental facies. The sedimentary systems of the Xujiahe Formation include alluvial fans, marine (lacustrine) deltas, and lacustrine environments. The Xujiahe Formation strata are divided into six members. The $\mathrm{Xu} 2$ Member $\left(\mathrm{T}_{3} \mathrm{x}^{2}\right)$, $\mathrm{Xu} 4$ Member $\left(\mathrm{T}_{3} \mathrm{x}^{4}\right)$, and $\mathrm{Xu} 6$ Member $\left(\mathrm{T}_{3} \mathrm{x}^{6}\right)$ are the main reservoir intervals in the study area, and their lithology consists primarily of fine-medium sandstone. The lithology of the $\mathrm{Xu} 1 \mathrm{Member}\left(\mathrm{T}_{3} \mathrm{x}^{1}\right), \mathrm{Xu} 3 \mathrm{Member}\left(\mathrm{T}_{3} \mathrm{x}^{3}\right)$, and $\mathrm{Xu} 5$ Member $\left(\mathrm{T}_{3} \mathrm{X}^{5}\right)$ is mainly black shale and mudstone with gray silt stone and sandstone. $T_{3} x^{1}$ and $T_{3} x^{2}$ are absent in the center and south of the basin (Fig. 1).

\section{Characteristics of grain-coating chlorite}

\subsection{Occurrences and formation time}

Chlorite is a complicated, layered aluminosilicate mineral that is composed primarily of $\mathrm{Fe}, \mathrm{Mg}, \mathrm{Si}$, and $\mathrm{Al}$. The chemical formula is as follows:

$$
\begin{aligned}
& \left(\mathrm{R}^{2+}, \mathrm{R}^{3+}\right)_{5-6}\left[(\mathrm{Si}, \mathrm{Al})_{4} \mathrm{O}_{10}\right](\mathrm{OH})_{8} \\
& \mathrm{R}^{2+}=\mathrm{Mg}, \mathrm{Fe}, \mathrm{Mn}, \mathrm{Ni} \\
& \mathrm{R}^{3+}=\mathrm{Al}, \mathrm{Fe}, \mathrm{Cr}, \mathrm{Mn}
\end{aligned}
$$

Chlorite group minerals have a stratified structure, consisting of alternating interlayers of talc and brucite. The majority of chlorites are monoclinic, though there are some triclinic polymorphs. Chlorite crystals mainly form either hexagonal sheets or tabular patterns, though a few are barrel shaped. The cross section of chlorite is either hexagonal or irregular flake shaped, while the longitudinal section of chlorite crystals is rectangular (Chang 2006). 


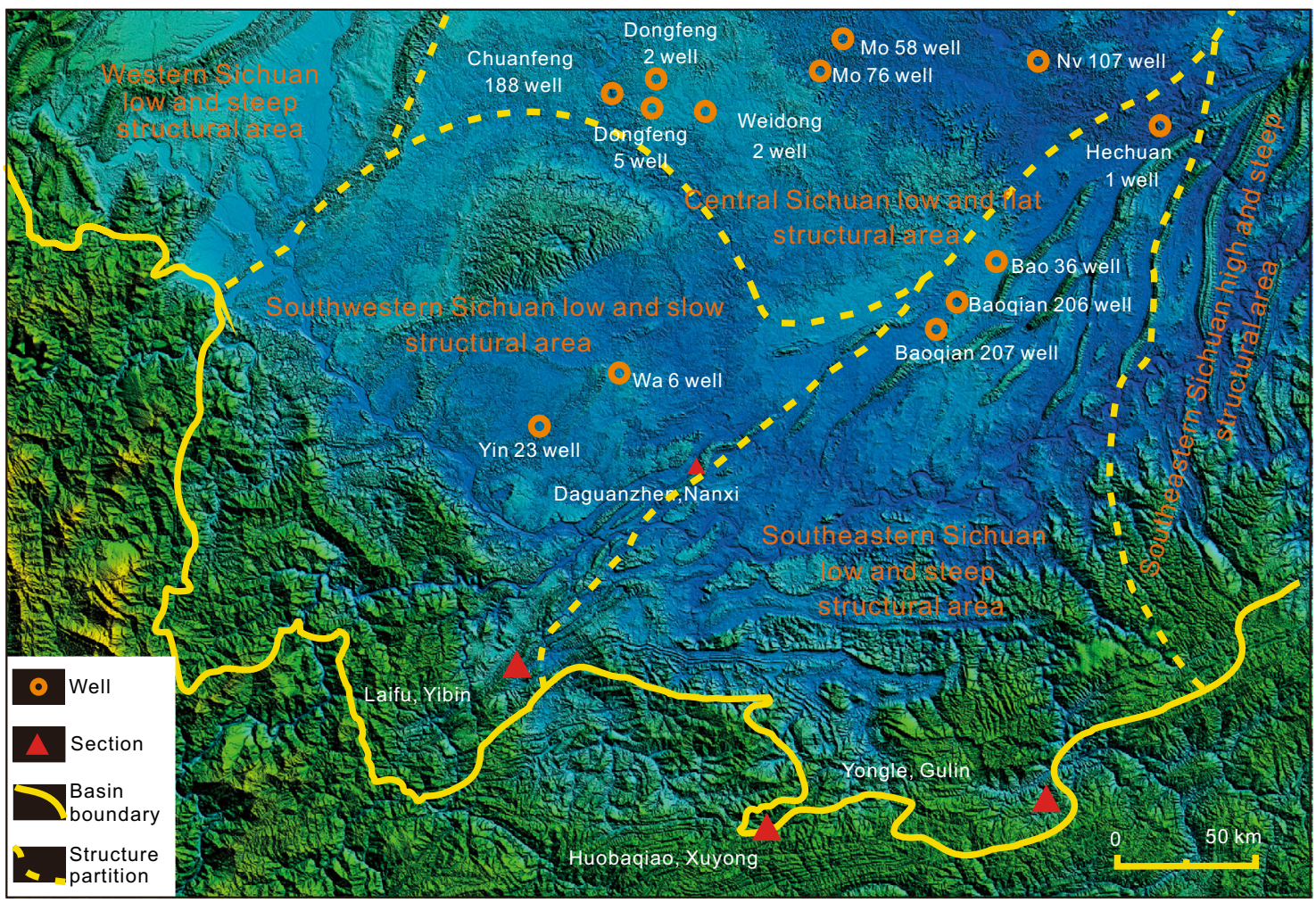

Fig. 1 Geological setting of study area, including well locations, basin boundaries, and structure delineations

Thin section and SEM analysis found that almost all authigenic chlorite grew around the grains (Fig. 2). Chlorite growth could clearly be observed on grain surfaces as scaly sheets in SEM images (Fig. 2e, f).

Authigenic chlorite in Xujiahe Formation sandstones has the following characteristics: (1) Because chlorite had already developed between grain contacts, it can be concluded authigenic chlorite formed on grain surfaces before mechanical compaction; (2) authigenic chlorite growths were found on the surface of quartz overgrowths and silica cement which filled in intergranular pores, indicating that authigenic chlorite may have formed after silica cementation; (3) chlorite was not found in intergranular dissolved pores or mouldpores, while chlorite has been found on the surface of feldspar grains with dissolved pores, suggesting authigenic chlorite formed before dissolution. These characteristics indicate authigenic chlorite growth in the Xujiahe Formation occurred in multiple phases. The first stage took place during syngenesis-early diagenesis A stage. Authigenic chlorite had already coated the grains before clastic grain contacts developed. This is also the formation stage of most authigenic chlorite in the study area. The second stage took place after silica cementation but before dissolution. Authigenic chlorite growths could be seen on the surface of silica cement, but chlorite was not found in intragranular dissolved pores. This suggests authigenic chlorite at this stage formed before aluminosilicate minerals were dissolved by organic acids. According to "China's Dividing Standard for Diagenetic Stage of Clastic Rocks (SY/T5477-2003)," the second stage of chlorite growth occurred around the end of early diagenesis A stage to the beginning of middle diagenesis A stage.

\subsection{Source material}

The formation process of authigenic chlorite in clastic rocks is still widely debated. Some researchers believe authigenic chlorite transformed from Fe-rich grain coating (Grigsby 2001; Lanson et al. 2002). Billault et al. (2003) thought authigenic chlorite precipitated from pore water. Clay minerals which transform into chlorite leave honeycomb-like structures which were not found in Xujiahe Formation sandstones. Most authigenic chlorite rims have nearly equal thicknesses, and most grain-coating chlorite formed during syngenesis-early diagenesis A stage. These characteristics suggest authigenic chlorite in the Xujiahe Formation sandstones mainly precipitated from pore waters and coat other grains.

Sandstones from the Xu 2 and Xu 4 Formation Members with grain-coating chlorite were selected for EPMA testing. The analyses were performed in the State Key Laboratory of Oil and Gas Reservoir Geology and Exploitation, Chengdu University of Technology (Table 1). Xujiahe Formation chlorite is mainly composed of $\mathrm{FeO}, \mathrm{SiO}_{2}$, 

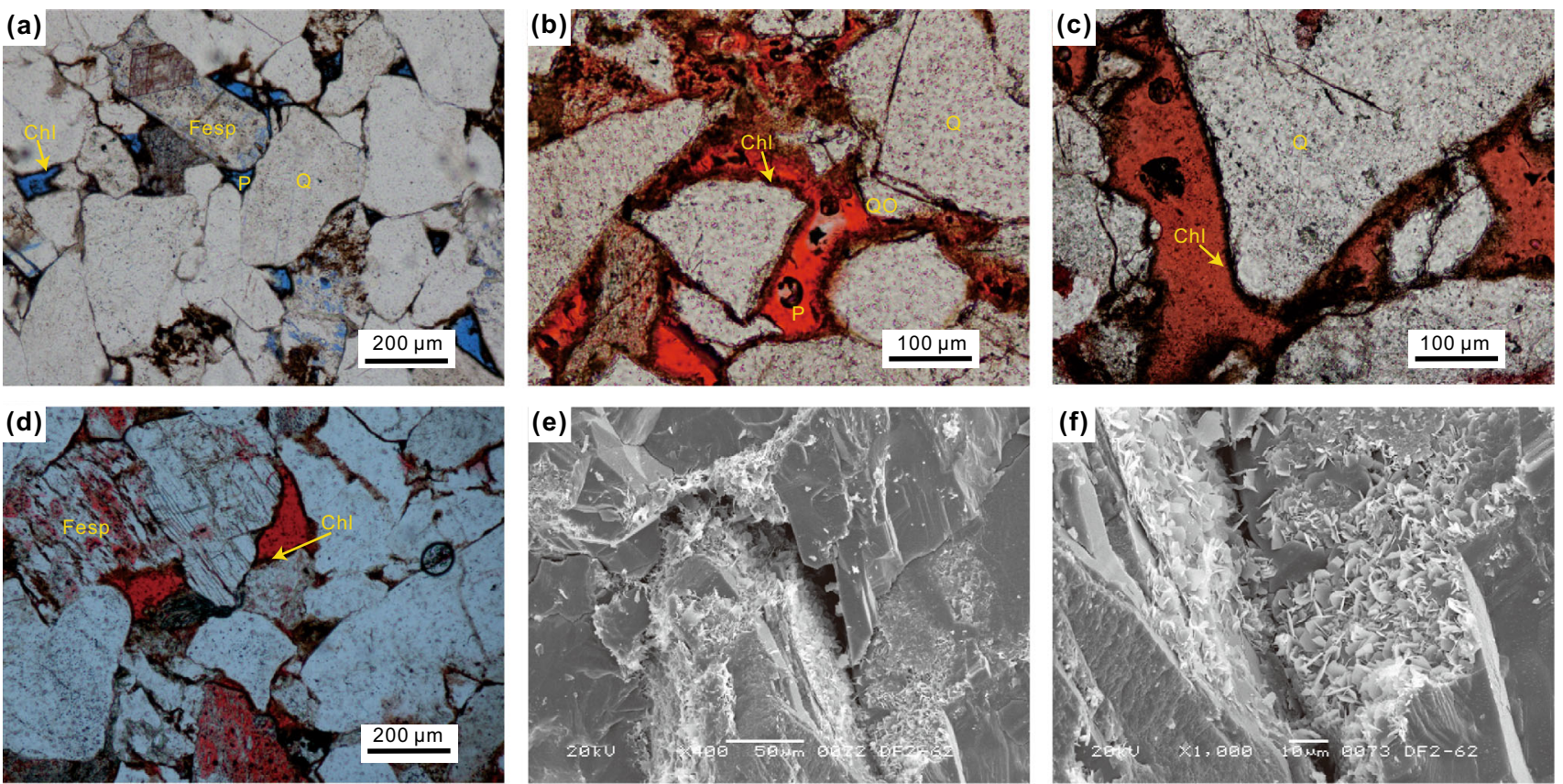

Fig. 2 Microphotographs of sandstone with grain-coating chlorite of the Xujiahe Formation in the southern Sichuan Basin. Figure descriptions including well numbers and formation are listed as follows: a authigenic chlorite coating grain, Lu 107 well, Xu 2 Member, PPL. b Authigenic chlorite growth on silica cement in top right corner, Hechuan 1 well, Xu 2 Member, PPL. c Authigenic chlorite growth on silica cement, Hechuan 1 well, Xu 2 Member, PPL. d Authigenic chlorite growth on feldspar surface with dissolved pores in grains, Bao 36 well, Xu 4 Member, PPL. e Scaly sheet chlorite sticking to the surfaces of quartz grains, Dongfeng 2 well, Xu 4 Member. f Zoom in e, Dongfeng 2 well, Xu 4 Member. Major minerals are abbreviated as $Q$ quartz, $Q O$ quartz overgrowth, Chl chlorite, $P$ pore, Fesp feldspar

Table 1 Primary mineral components of authigenic grain-coating chlorite in Xujiahe Formation sandstones $\left(\times 10^{-2}\right)$

\begin{tabular}{lcrcccl}
\hline Age & $\mathrm{FeO}$ & $\mathrm{Al}_{2} \mathrm{O}_{3}$ & $\mathrm{MgO}$ & $\mathrm{SiO}_{2}$ & $\mathrm{~K}_{2} \mathrm{O}$ & $\mathrm{CaO}$ \\
\hline Xu 2 Member & 50.35 & 10.91 & 0.85 & 27.99 & 1.39 & 0.54 \\
Xu 4 Member & 52.56 & 8.20 & 1.61 & 35.46 & 1.14 & 0.729
\end{tabular}

$\mathrm{Al}_{2} \mathrm{O}_{3}$, and other oxides. Fe is the most important chemical component of authigenic chlorite.

Previous studies showed that iron ions in clastic rock chlorite were mainly derived from alteration of iron-rich debris (Billault et al. 2003; Bloch $S$ et al. 2002). As rivers flow into the ocean, ferruginous components formed flocculent precipitates and become a source of chlorite (Grigsby 2001) and filled mudstones with iron and magnesium ion-rich fluids (Hilier et al. 1996). After thin section analysis, study area debris was identified mainly as sedimentary and metamorphic rock debris, with minor amounts of iron-rich volcanic rock debris. Therefore, the study rules out the theory that $\mathrm{Fe}$ was derived from the alteration of iron-rich debris. The $\mathrm{Xu} 1, \mathrm{Xu} 3$, and $\mathrm{Xu} 5$ Members of the Sichuan Basin are composed primarily of mudstone and argillaceous siltstone. During periods of sea (lake) expansion, iron ion could be provided for reservoirs such as the Xu 2 and $\mathrm{Xu} 4$ Members. Authigenic graincoating chlorite formed during these periods of rising base level. As mudstones were filled with iron- and magnesiumrich fluids, magnesium ions reacted with iron-rich grain coatings to form grain-coating chlorite. In conclusion, the iron content of grain-coating chlorite in mudstone did not precipitate from pore water.

The relative content of authigenic chlorite in different sedimentary microfacies was determined from thin section analysis, and the results are shown in Fig. 3. Authigenic chlorite distribution was controlled by the sedimentary environment and mainly developed in underwater distributary channels, distributary channel, shallow lake sandstone dam, mouth bar facies, etc. The first three environments belong to delta sedimentary facies, and mouth bars belong to shore-shallow lake sedimentary facies. However, evidence of suspended boulder-sized particles was found in the fluvial environments, which require highly hydrodynamic conditions.

Therefore, this study proposes that the iron component of authigenic chlorite was mainly derived from flocculent precipitates formed when rivers flow into the ocean. The difference between electrolyte composition and the colloidal properties of river water and sea water (lake water) 

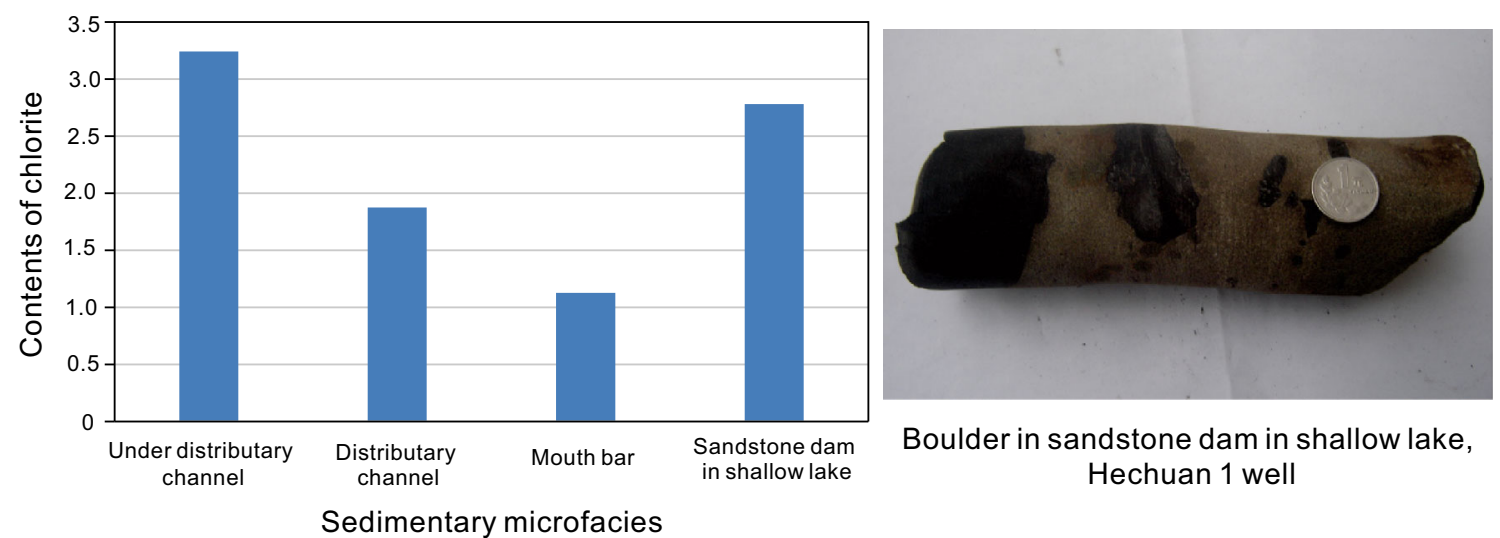

Fig. 3 Comparison of grain-coating chlorite content in different sedimentary microfacies, including: underwater distributary channels, distributary channels, mouth bars, and shallow lake sandstone dams

resulted in flocculation and the formation of iron-rich precipitates (Huang et al. 2004; Ehrenberg 1993; Yao et al. 2011). Gould et al. (2010) indicated primary grain-coating chlorite was formed by ferruginous flocculent precipitates above the sulfate-reduction zone. The formation of primary grain-coating chlorite is similar to the formation process of oolitic lime, which requires highly hydrodynamic conditions and for grains to constantly adsorb flocculent precipitates from the water (Yao et al. 2011). Therefore, graincoating chlorites are most likely to form in highly hydrodynamic environments, such as underwater distributary channel sandstone bodies.

\subsection{Paragenetic mineral characteristics}

Based on thin section analysis, this study finds that sandstone sequences with grain-coating chlorite tend to have relatively well-developed glauconite and pyrite. Pyrite is mostly granular with an intergranular or zonal distribution (Fig. $4 \mathrm{a}-\mathrm{c}$ ). Semi-saline water and iron-rich conditions are favorable for pyrite formation, and the appearance of pyrite in the study section indicates a reducing environment.

Glauconite is a sedimentary mineral with the molecular formula: $\mathrm{K}_{1-x}\left\{(\mathrm{Al}, \mathrm{Fe})_{2}\left[\mathrm{Al}_{1-x} \mathrm{Si}_{3+x} \mathrm{O}_{10}\right](\mathrm{OH})_{2}\right\}$. Glauconite is thought to be an indicator mineral of marine sedimentary environments, especially transgressive facies, and formed in warm shallow oceans with abundant organic matter over long periods of time (Chang 2006). Glauconite in the Xujiahe Formation sandstones mostly appears emerald and light green under the microscope, brighter than chlorite, with irregular clumps and a granular appearance (Fig. 4d-f). Glauconite tends to have a soft, gel-like texture after deposition, which makes it easy for the intrusion of other grains and the formation of irregular shapes.

The glauconite was analyzed by EPMA (Table 2). The main chemical components included $\mathrm{FeO}, \mathrm{SiO}_{2}$ and $\mathrm{Al}_{2} \mathrm{O}_{3}$ and were comparable to the composition of modern glauconite (Chen 1994). Glauconite in Xujiahe Formation sandstones tends to exhibit characteristics of "high Al, low $\mathrm{Fe}$, and high K content". Potassium $(\mathrm{K})$ content is the key indicator of glauconite maturity. Primary glauconite is indicated when $\mathrm{K}_{2} \mathrm{O}$ content is less than $4 \%, \mathrm{~K}_{2} \mathrm{O}$ between $4 \%$ and $6 \%$ indicates low maturity glauconite, $\mathrm{K}_{2} \mathrm{O}$ between $6 \%$ and $8 \%$ indicates moderately mature glauconite, while $\mathrm{K}_{2} \mathrm{O}$ values greater than $8 \%$ indicate highly mature glauconite (Odin and Matter 1981). Previous studies show that $\mathrm{Fe}$ content in glauconite would be replaced by Al during diagenesis. At the same time, $\mathrm{K}$ would be absorbed from pore waters which results in an increase of $\mathrm{Al}_{2} \mathrm{O}_{3}$ and $\mathrm{K}_{2} \mathrm{O}$, while $\mathrm{FeO}$ content decreases. Marine sedimentary glauconite exhibits "high $\mathrm{Al}$, low $\mathrm{Fe}$ " (Chen 1994). In conclusion, the Xujiahe Formation glauconites exhibit marine sedimentary glauconite characteristics.

\subsection{Relationship of grain-coating chlorite and reservoir porosity}

Based on identification of cast thin sections, the study found that the Xujiahe Formation reservoir space is composed of primary intergranular pores, solution pores, and microfractures. Analysis of the relationship between authigenic grain-coating chlorite content and surface porosity, primary intergranular pore porosity, solution porosity, and sample porosity (Fig. 5) shows that the correlation between chlorite content to surface porosity and sample porosity is very poor, while the correlation with primary intergranular porosity is positive, and the correlation with solution porosity is negative.

The results of this study indicate authigenic graincoating chlorite has a good positive correlation with primary intergranular porosity, a conclusion shared with the studies by Sun et al. (2012, 2014) and Xiang et al. (2016). Many researchers thought grain-coating chlorite was 

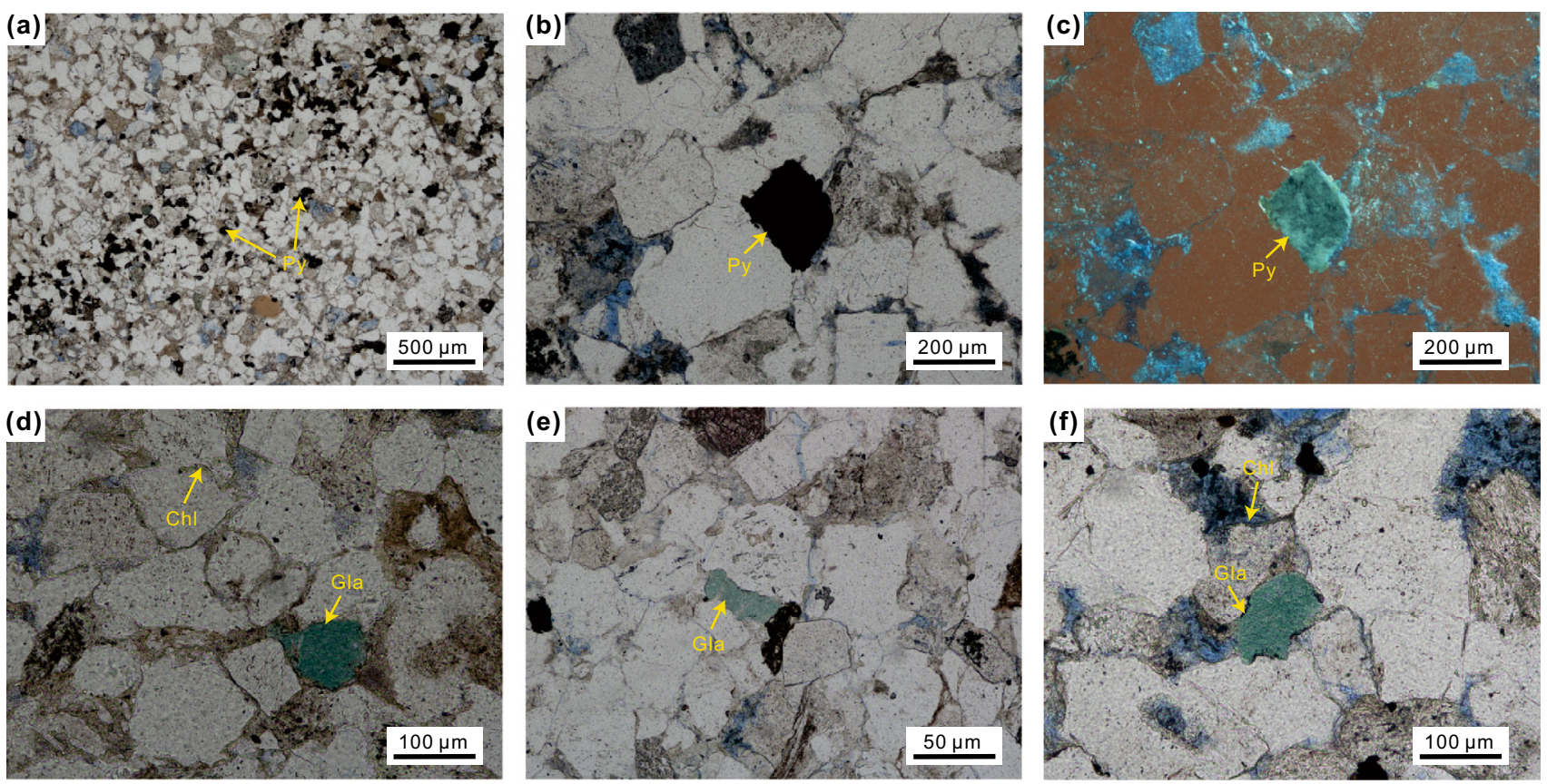

Fig. 4 Characteristics of pyrite and glauconite in Xujiahe Formation sandstones. a Black granular pyrite with zonal distribution, Weidong 2 well, Xu 2 Member, PPL. b Black granular pyrite, Weidong 2 well, Xu 2 Member, PPL. c Reflected light thin section of image b. d Irregular, granular glauconite with grain-coating chlorite on the surface, Weidong 2 well, Xu 2 Member, PPL. e Irregular granular glauconite, Mo 76 well, Xu 2 Member, PPL. f Granular glauconite, grain-coating chlorite developed on the grain surface, Weidong 2 well, Xu 2 Member, PPL. Py Pyrite, Gla glauconite, Chl chlorite

Table 2 Main chemical components of glauconite in Xujiahe Formation sandstones $\left(\times 10^{-2}\right)$

\begin{tabular}{lllllllll}
\hline Components & $\mathrm{Na}_{2} \mathrm{O}$ & $\mathrm{SiO}_{2}$ & $\mathrm{FeO}$ & $\mathrm{CaO}$ & $\mathrm{Al}_{2} \mathrm{O}_{3}$ & $\mathrm{MnO}$ & $\mathrm{K}_{2} \mathrm{O}$ & $\mathrm{MgO}$ \\
\hline Study area & 0.06 & 49.68 & 12.5 & 0.23 & 18.68 & 0.02 & 7.9 & 3.37 \\
Modern $^{\mathrm{a}}$ & 0.43 & 44.20 & 25.07 & 2.43 & 5.08 & 0.07 & 3.28 & 5.84 \\
\hline
\end{tabular}

${ }^{a}$ Data are cited from Chen (1994) beneficial to reservoir porosity preservation, especially for primary intergranular pores. However, some researchers believed good-quality reservoirs develop as a result of good primary intergranular porosity, and the existence of grain-coating chlorite is only indicative of primary intergranular porosity (Xiang et al. 2016). Based on the correlation of chlorite content with surface porosity and sample porosity in this study, it was concluded that the development of chlorite did not play a positive role in the reservoir porosity preservation and it may have influenced dissolution, to a certain extent. This may be attributed to two reasons: (1) As primary intergranular porosity increased with chlorite content, acidic fluids flowed into the reservoir, and the increased pore space diluted the acidic fluids, reducing the effects of dissolution; (2) it is rare to find authigenic chlorite grains in areas which have not undergone dissolution; therefore, the increased chlorite content may cause a reduction in solution porosity. Further study is needed to discover the effects of authigenic grain-coating chlorite on reservoir porosity preservation. However, the effects of chlorite development on sandstone reservoir properties are not disputed.

\section{Characteristics of sand bodies with grain- coating chlorite}

Sand bodies with authigenic grain-coating chlorite in the study area may be divided into four types of sedimentary microfacies: underwater distributary channels, distributary channel, shallow lake sandstone dams, and mouth bars.

\subsection{Sandstone dam in shallow lake}

Figure 6 shows the characteristics of a sandstone dam in the shallow lake environment of the Hechuan 1 well in the $\mathrm{Xu} 2$ Member in the study area. Tabular cross-bedding is developed at the bottom of the sand body, and there are 
(a)

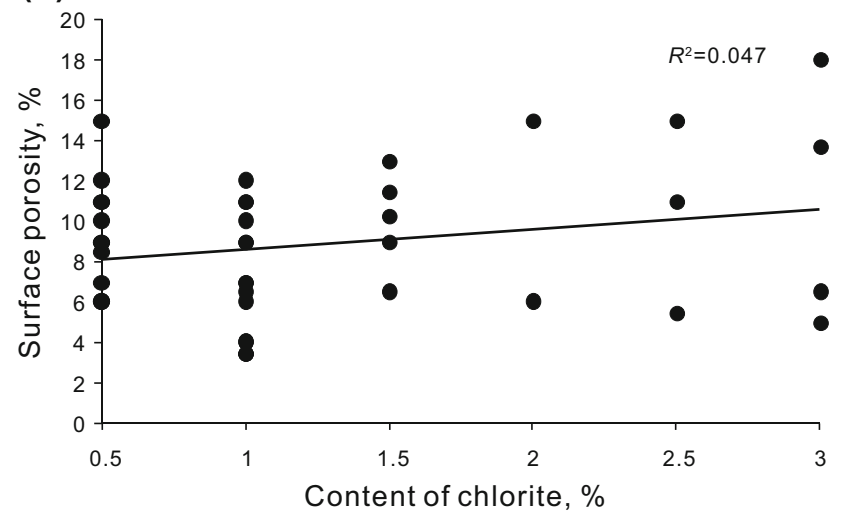

(c)

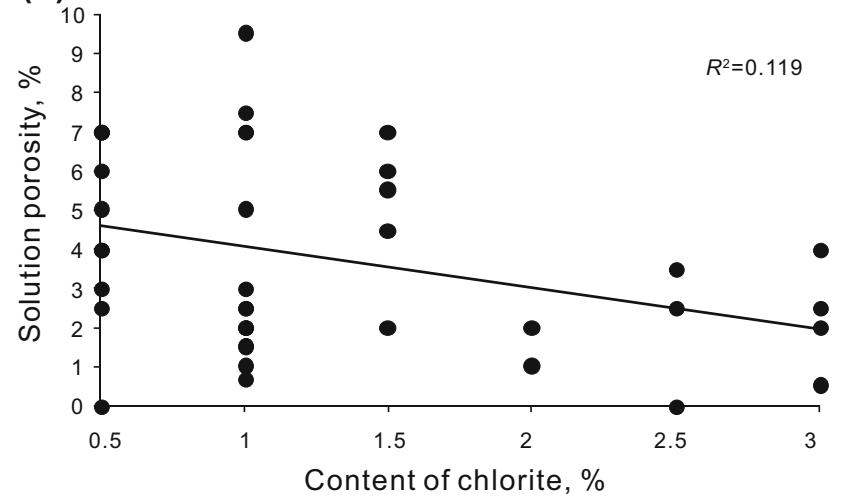

(b)

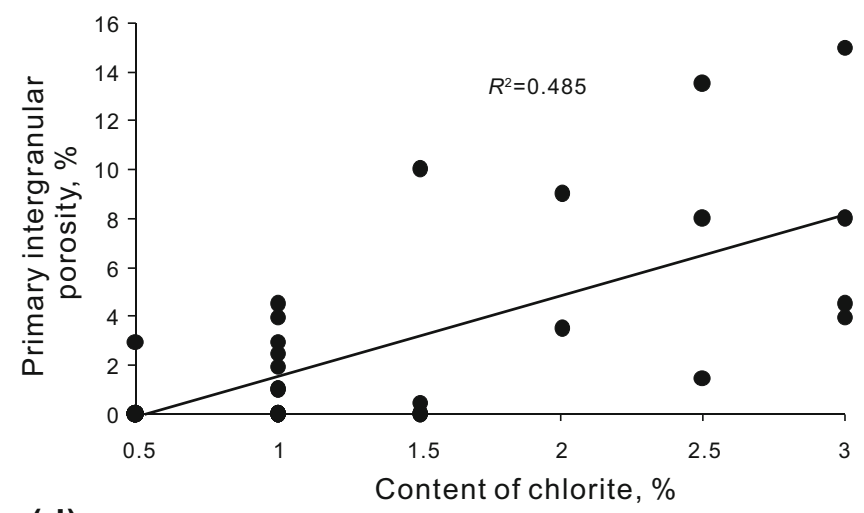

(d)

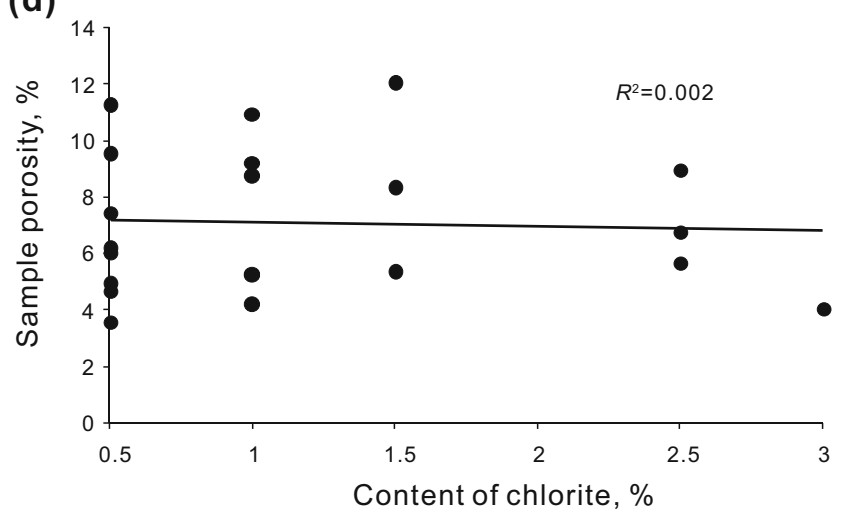

Fig. 5 Correlation of authigenic grain-coating chlorite content with: a surface porosity; b primary intergranular porosity; c solution porosity; and d sample porosity. The results indicate chlorite content has a positive correlation with primary intergranular porosity and surface porosity, a negative correlation with solution porosity, and a poor negative correlation with sample porosity

boulder-sized grains in contact with the lower shale. The development of upward progradation in the sand body can be considered as the result of the rising base-level cycle. Thin section analysis shows that grain-coating chlorite was poorly developed at the bottom of sand bodies with poor sorting (Fig. 6a). Higher muddy matrix content also results in poor porosity. However, muddy matrix content is lower in the upper sand bodies as shown in Fig. 6b, c. The upper sand bodies also have well-developed grain-coating chlorite with good porosity. The upper sand bodies also have intergranular pores conducive to the formation of good reservoirs.

\subsection{Distributary channel}

Figure 7 shows a sand body which developed in a distributary channel and swamp with a burial depth of 2100-2200 m in the Bao 36 well and the Xu 4 Member. The sand body is divided into two base-level rising cycles because there are two gravel horizons at 2200 and $2155 \mathrm{~m}$. Two sandstone horizons dominated by cementation of authigenic chlorite developed at depths of 2120 and $2155 \mathrm{~m}$. The upper horizon with developed chlorite also contains high amounts of silica cement which filled in intergranular pores (Fig. 7a, b). As a result, the porosity of the lower horizon is higher than that of the upper horizon. The high content of silica cement in the upper horizon is related to the upper covered mudstone or shale, as during diagenesis, montmorillonite would be converted into illite and release large amounts of $\mathrm{SiO}_{2}$. Fluids containing $\mathrm{SiO}_{2}$ move to the lower layers and cause the precipitation of silica cements in intergranular pores.

\subsection{Underwater distributary channel}

The sand body shown in Fig. 8 is buried at a depth ranging from 2050 to $2080 \mathrm{~m}$ in the $\mathrm{Xu} 4$ Member in the Bao 36 well. The sedimentary facies of the sand body include distributary channels and swamp, underwater distributary channels, and peat flats. Grain-coating chlorite in the sand body mainly developed in underwater distributary channels.

\subsection{Mouth bar}

Figure 9 shows a lithologic log of the Xu 2 Member in the Weidong 2 well from 2140 to $2157 \mathrm{~m}$. The sedimentary microfacies were divided into underwater distributary channel, mouth bar, and peat flat. Grain-coating chlorite 


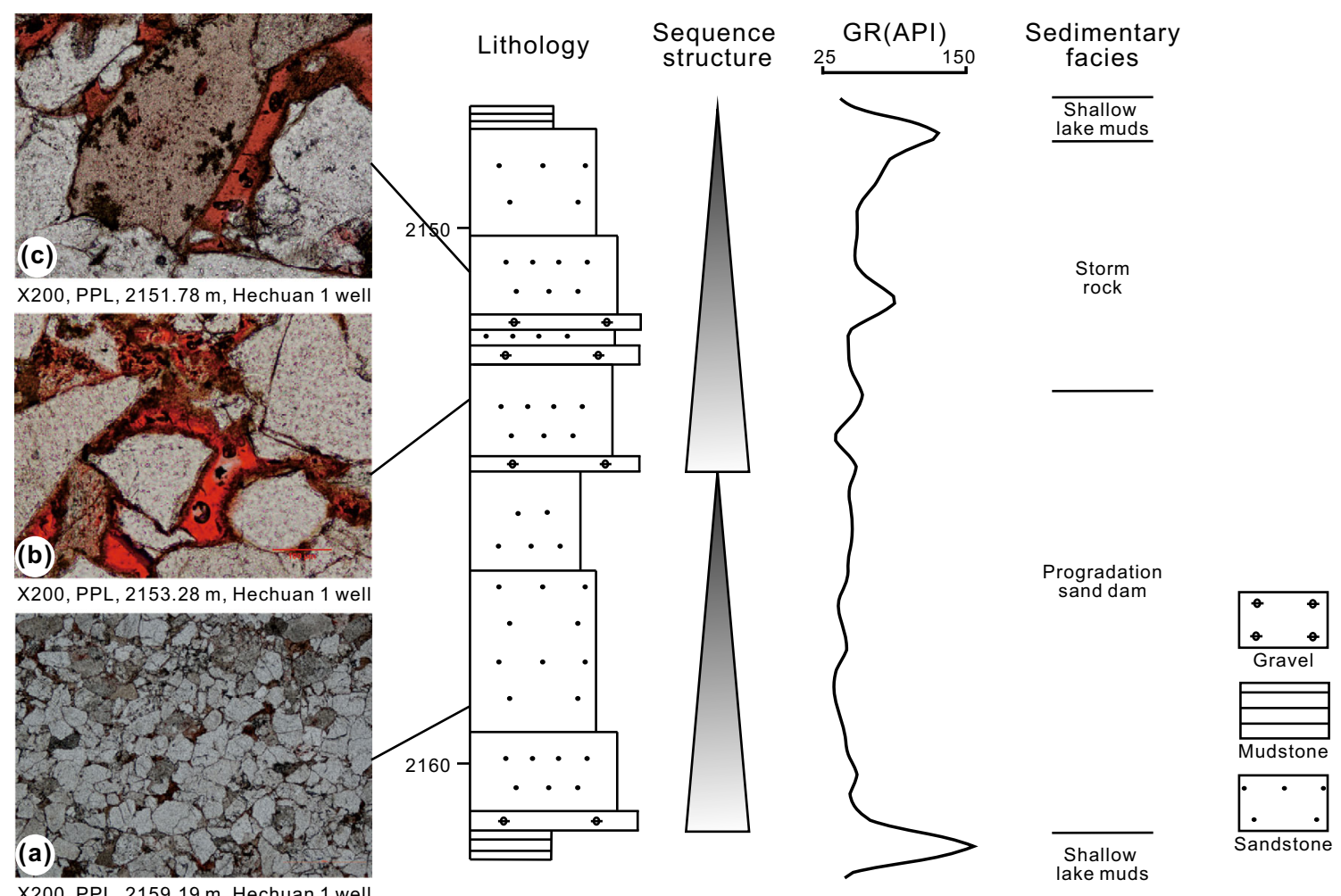

Fig. 6 Lithologic log and characteristics of shallow lake sandstone dam samples taken from the Hechuan 1 well. Photomicrographs of samples taken from the Hechuan 1 well at depths of a $2159.19 \mathrm{~m}$; b $2153.28 \mathrm{~m}$; and c $2151.78 \mathrm{~m}$

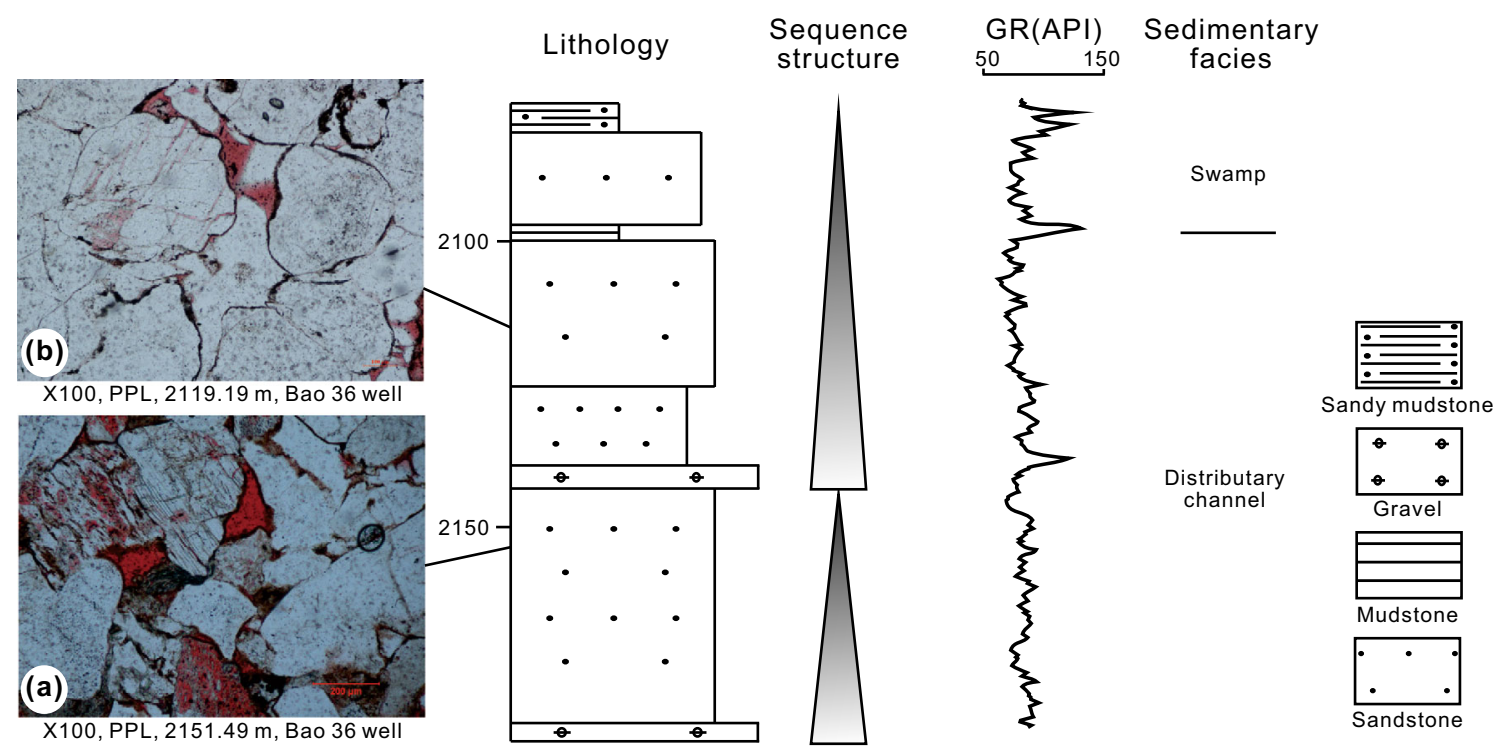

Fig. 7 Lithology and characteristics of distributary channel sand bodies taken from Bao 36 well samples. Photomicrographs of samples from depths of a $2151.49 \mathrm{~m}$ and b $2119.19 \mathrm{~m}$

mainly developed in the upper part of the mouth bar sand body. Primary porosity rarely formed due to strong compaction, although considerable secondary porosity formed due to dissolution (Fig. 10).
Based on the four types of chlorite-containing sand microfacies, grain-coating chlorite was found almost exclusively in the upper part of sandstone bodies, which indicates rising sea level. Base level is an abstract surface 

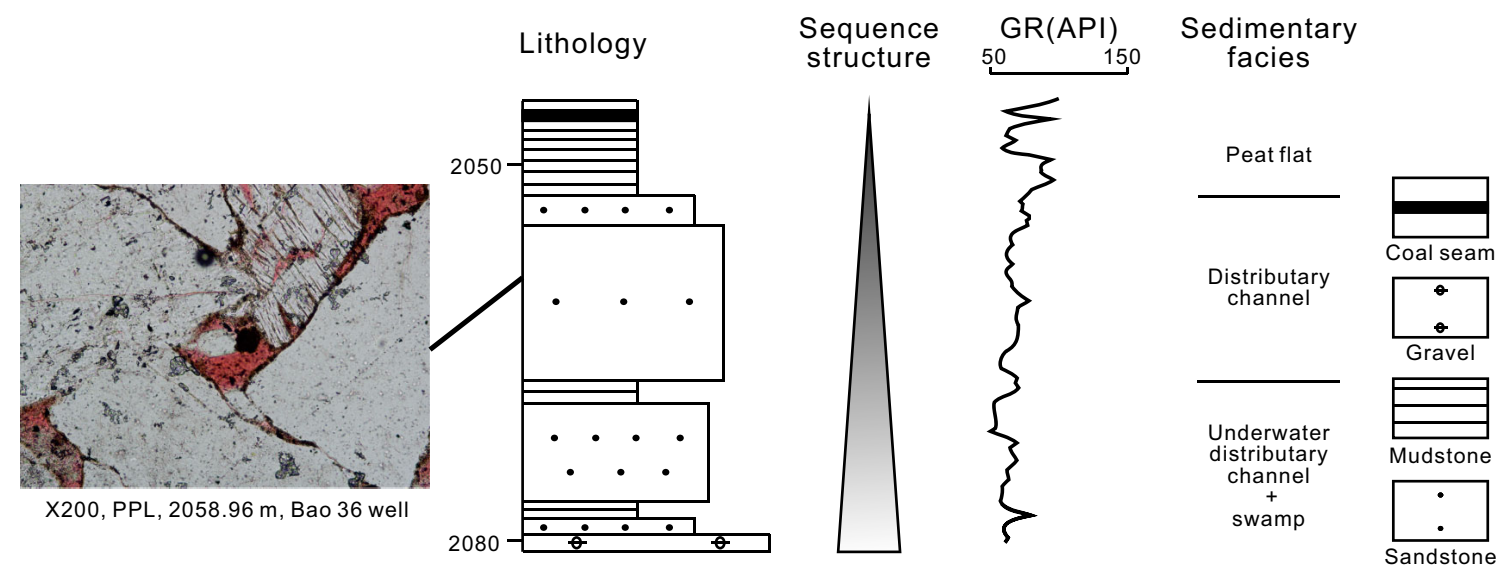

Sedimentary

Fig. 8 Characteristics of underwater distributary channel
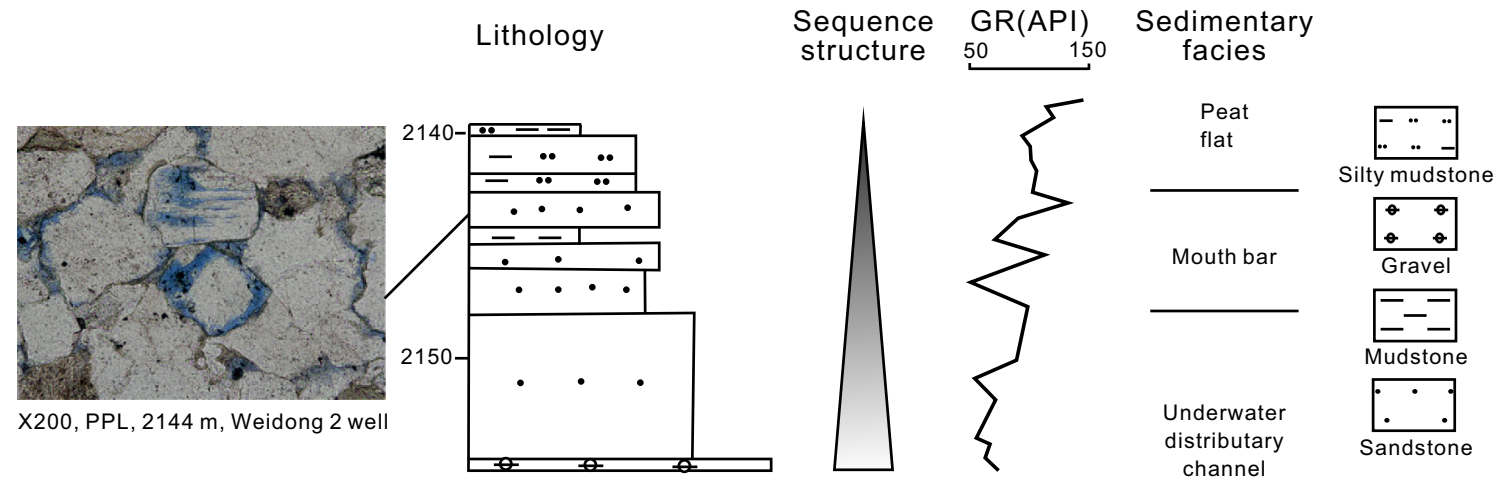

Fig. 9 Mouth bar characteristics

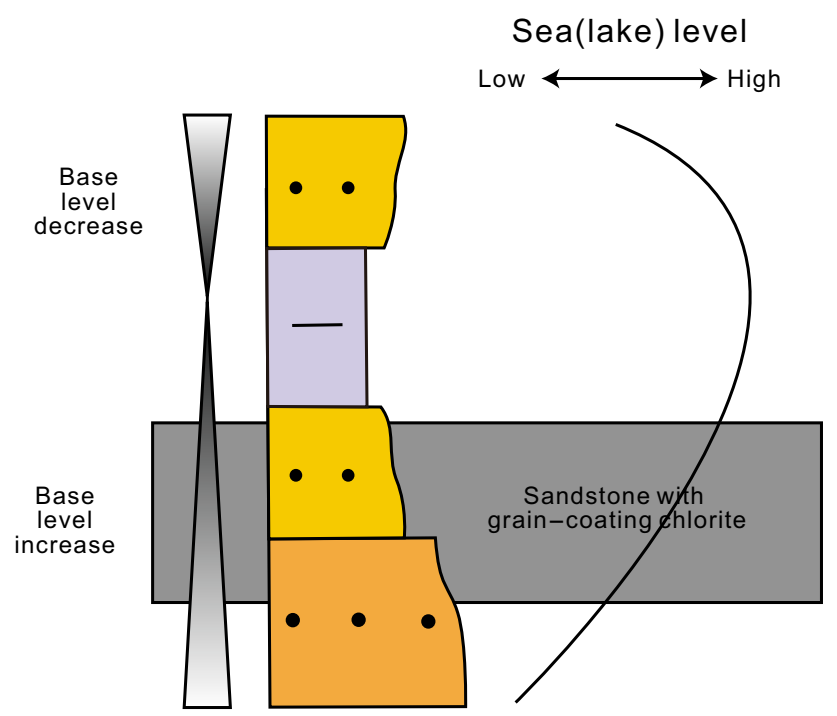

with time (Deng et al. 2000). For simplicity, base level is usually equivalent to sea (lake) level. An increase in base level is indicative of marine (lacustrine) transgression.

\section{Formation model of grain-coating chlorite in the Xujiahe Formation}

The evidence shown above indicates that grain-coating chlorite formed in high hydrodynamic, weak alkaline, weakly reducing, and iron-rich conditions. By analyzing authigenic grain-coating chlorite horizons, the study found that while chlorite mainly formed at the base of the sand bodies, it experienced a large increase in content, especially in the upper part of the sandstone bodies. What causes it?

Previous studies show that the Sichuan Basin shifted

Fig. 10 Relationship between developed grain-coating chlorite horizon and sequence

that is equivalent to continuous, wave-like movement on the earth's surface with a slight declination to the basin. Its location, direction of motion, and change in elevation vary from a marine to a continental sedimentary environment. Because of the influence by the An'xian movement in the $\mathrm{Xu} \mathrm{4,} \mathrm{the} \mathrm{ancient} \mathrm{Longmen} \mathrm{Mountain} \mathrm{thrust} \mathrm{belt} \mathrm{was}$ uplifted and transformed the Sichuan Basin into a terrestrial sedimentary environment (Lin et al. 2006). Although 


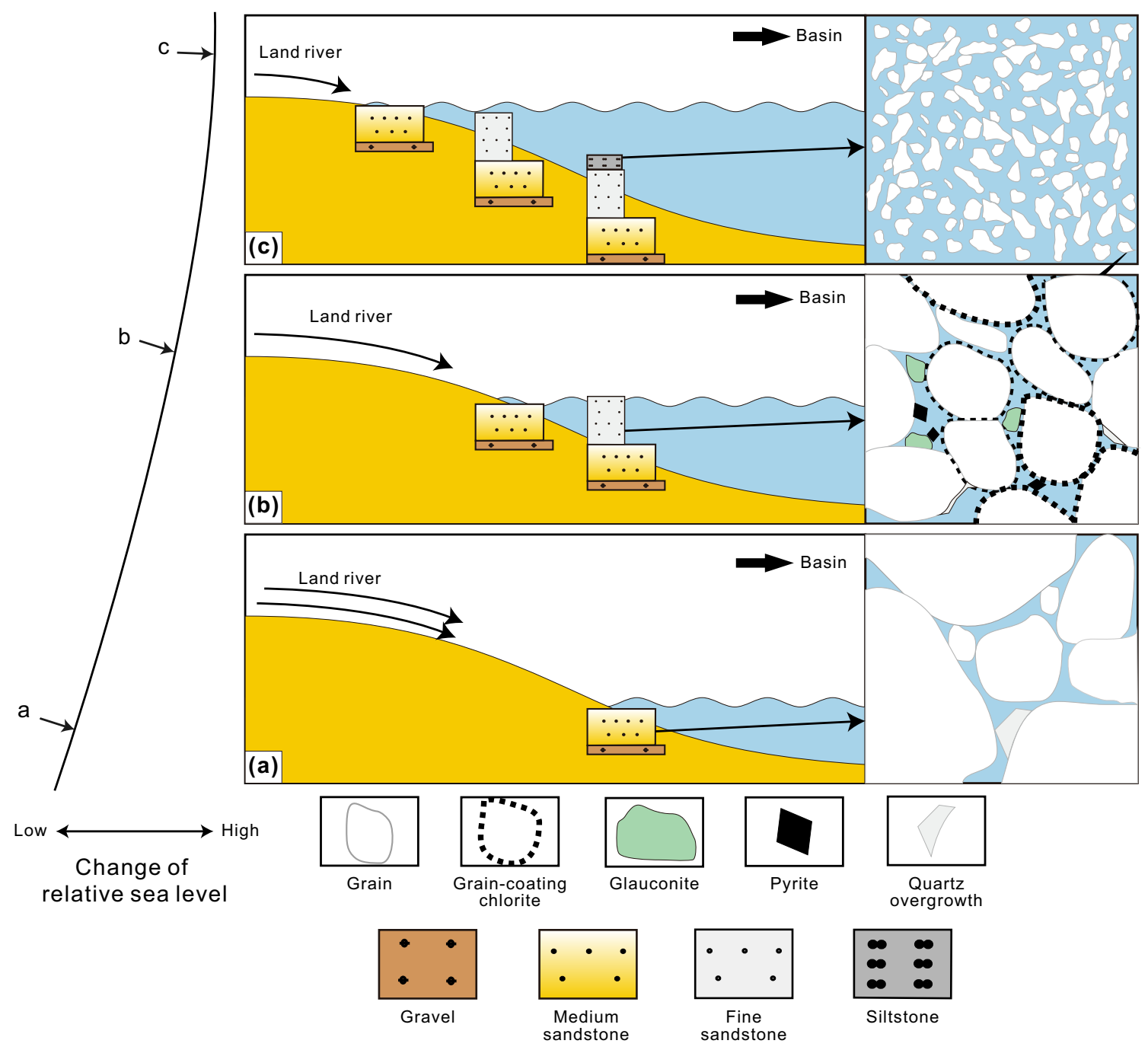

Fig. 11 Formation model of grain-coating chlorite

the Sichuan Basin was already in a continental sedimentary environment during $\mathrm{Xu} 4$ deposition, the lake water was still slightly saline to semi-saline as the basin was just cut off from the Paleo-Tethys sea. Because of the inherited properties of ocean water, the $\mathrm{Xu} 4$ lake water had semisaline characteristics and could be distinguished from Xu 2 sea water in terms of salinity, $\mathrm{pH}$, and other characteristics.

Grain-coating chlorite, glauconite, and pyrite are all iron-rich and can form authigenically. Based on findings of this study, $\mathrm{Fe}$ was thought to be derived from the flocculent precipitates formed when rivers flowed into the ocean. The sand bodies of the Xujiahe Formation typically indicate increasing base level and generally contain gravel. The bottom layers usually include river rejuvenation surfaces or river erosion surfaces and generally contain gravel which overlaps with the lower black mudstone or shale, indicating when base level started to increase. Decreasing base level exposes previously deposited sediments to the surface. The influx of fresh water from rivers would reduce $\mathrm{pH}$ and salinity, where the environment could not reach the conditions for the deposition of grain-coating chlorite or glauconite. As base level rose, the $\mathrm{pH}$ and salinity of sea (lake) water began to rise and the sedimentary environment shifted from weakly oxidizing to weakly reducing. When the $\mathrm{pH}$ became weakly alkaline, the sedimentary environment became weakly reducing. Pyrite began to deposit, while chlorite and glauconite were deposited as grain coating and crystal grains, respectively (Fig. 11b).

However, grain-coating chlorite is rarely observed in study area sand bodies which developed during periods of decreasing base level. The shift in base level may be related to megamonsoons during the Carnian-Raleigh of Late Triassic Epoch (Shi et al. 2010) in the Middle and Upper Yangtze regions of the Sichuan Basin. The monsoon climate resulted in uneven rainfall distribution and seasonal humidity. During periods of increased rainfall, river 
discharges increased and more $\mathrm{Fe}$ particulates were deposited. Water was relatively more saturated in $\mathrm{Fe}$, and Fe-rich minerals such as chlorite became easier to deposit. The rising base level resulted in the formation of additional sand body cycles because of increased river discharges. During the even longer seasonal dry periods, river flow decreased and less $\mathrm{Fe}$ particulates were deposited. This resulted in less grain-coating chlorite and the sand bodies formed reflected decreased base level. This model assumes lake level would only be affected by rainfall while ignoring the influence of tectonic activity.

Based on this chlorite formation model, authigenic chlorite-containing sandstones can be identified with greater certainty. During periods of high water level, areas which once deposited authigenic chlorite began to deposit siltstone due to rising base level. When the values of $\mathrm{pH}$ and oxidation-reduction potential (ORP) reached the conditions necessary for authigenic chlorite deposition in shallow water environments, grain-coating chlorite began to deposit in sand bodies.

\section{Conclusions}

Authigenic chlorite growth in the southern Sichuan Basin Xujiahe Formation was found to have occurred in multiple phases and mostly formed during syngenesis-early diagenesis A stage based on thin section and SEM analysis of grain-coating chlorite. Ferruginous minerals were derived from flocculent precipitates which formed as rivers flowed into the ocean, and chlorite formed in weak alkaline, weakly reducing environments with high hydrodynamic conditions. The sedimentary microfacies could be divided into underwater distributary channel, distributary channel, shallow lake sandstone dam, mouth bar, etc., based on analysis of authigenic chlorite-containing sandstone bodies from the southern Sichuan Xujiahe Formation. Chlorite had a tendency to form in the upper part of sandstone bodies, indicating increased base level. The increase in base level may result from lacustrine transgression related to Late Triassic megamonsoons in the Middle and Upper Yangtze Region. During periods of abundant precipitation, river discharges increased and more Fe particulates were brought to the lake. Base level would increase or decrease over short periods in response to precipitation. As the sedimentary environment shifted from weakly oxidizing to weak alkaline, weakly reducing because of increased base level, Fe-rich minerals such as authigenic chlorite and glauconite started to form and deposit.

Acknowledgments This study is financially supported by the National Science and Technology Major Project of the Ministry of
Science and Technology of China (Nos. 2011ZX05002-004-006HZ, 2016ZX05002-004-010).

Open Access This article is distributed under the terms of the Creative Commons Attribution 4.0 International License (http://crea tivecommons.org/licenses/by/4.0/), which permits unrestricted use, distribution, and reproduction in any medium, provided you give appropriate credit to the original author(s) and the source, provide a link to the Creative Commons license, and indicate if changes were made.

\section{References}

Bahlis AB, Luiz F. Origin and impact of authigenic chlorite in the Upper Cretaceous sandstone reservoirs of the Santos Basin, eastern Brazil. Pet Geosci. 2013;19(2):185-99.

Billault V, Beaufort D, Baronnet A, et al. A nanopetrographic and textural study of grain-coating chlorites in sandstone reservoirs. Clay Miner. 2003;38(3):315-28.

Bloch S, Lander RH, Bonnell L. Anomalously high porosity and permeability in deeply buried sandstone reservoirs: origin and predictability. AAPG Bull. 2002;86(2):301-28.

Chang LH. Identification manual of transparent minerals in thinsection. Beijing: Geological Publishing House. 2006. 1-235; (in Chinese).

Chen LR. Evolution of authigenic glauconite in early diagenesis. Chin Sci Bull. 1994;39(18):1550-3.

Deng HW, Wang HL, Ning N. Sediment volume partition principle: theory basis for high-resolution sequence tratigraphy. Earth Sci Front. 2000;7(4):305-13 (in Chinese).

Ding XQ, Han MM, Zhang SN. The role of provenance in the diagenesis of siliciclastic reservoirs in the Upper Triassic Yanchang Formation, Ordos Basin, China. Pet Sci. 2013;10(2): 149-60.

Ehrenberg SN. Preservation of anomalously high porosity in deeply buried sandstones by grain-coating chlorite: examples from the Norwegian continental shelf. AAPG Bull. 1993;77(7):1260-86.

Gould K, Pe-Piper G, Piper D. Relationship of diagenetic chlorite rims to depositional facies in Lower Cretaceous reservoir sandstones of the Scotian Basin. Sedimentology. 2010;57(2): 587-610.

Grigsby JD. Origin and growth mechanism of authigenic chlorite in sandstones of the Lower Vicksburg Formation, South Texas. J Sediment Res. 2001;71(1):27-36.

Gu N, Tian JC, Zhang X, et al. Densification mechanism analysis of sandstone densification within Xujiahe Formation in low-step structure in southern Sichuan Basin. J Northeast Pet Univ. 2014;38(5):7-14 (in Chinese).

Hilier S, Fallick AE, Matter A. Origin of pore-lining chlorite in the aeolian Rotliegend of northern Germany. Clay Miner. 1996;31(2):153-71.

Huang SJ, Xie LW, Zhang M, et al. Formation mechanism of authigenic chlorite and relation to preservation of porosity in nonmarine Triassic reservoir sandstones, Ordos Basin and Sichuan Basin, China. J Chengdu Univ Technol Sci Technol Ed. 2004;31(3):273-81 (in Chinese).

Huang J, Zhu RK, Hou DJ, et al. Influences of depositional environment and sequence stratigraphy on secondary porosity development: a case of the Xujiahe Formation clastic reservoir in the central Sichuan Basin. Pet Explor Dev. 2010;37(2):158-66 (in Chinese).

Lanson B, Beaufort D, Berger G, et al. Authigenic kaolin and illitic minerals during burial diagenesis of sandstones: a review. Clay Miner. 2002;37(1):1-22. 
Lin LB, Chen HD, Zhai CB, et al. Sandstone compositions and paleogeographic evolution of the Upper Triassic Xujiahe Formation in the Western Sichuan Basin, China. Pet Geol Exp. 2006;28(6):511-7 (in Chinese).

Lin LB, Yu Y, Gao J, et al. Main control factors of Xujiahe Formation sandstone reservoir in South Sichuan, China. J Chengdu Univ Technol Sci Technol Ed. 2015;42(4):400-9 (in Chinese).

Liu JK, Peng J, Liu JJ, et al. Pore-preserving mechanism of chlorite rims in tight sandstone - an example from the $\mathrm{T}_{3} \mathrm{x}$ Formation of Baojie area in the transitional zone from the central to southern Sichuan Basin. Oil Gas Geol. 2009;30(1):53-60 (in Chinese).

Liu LY, Qu ZH, Sun W, et al. Properties of clay mineral of clastic rock in Shanshan oil field, Xinjiang. J Northwest Univ Nat Sci Ed. 1998;28(5):77-80 (in Chinese).

Lü ZX, Ye SJ, Yang X, et al. Quantification and timing of porosity evolution in tight sand gas reservoirs: an example from the Middle Jurassic Shaximiao Formation, western Sichuan, China. Pet Sci. 2015;12(2):207-17.

Odin GS, Matter A. De glauconarium origine. Sedimentology. 1981;28:611-41.

Okwese AC, Pe-Piper G, Piper D. Controls on regional variability in marine pore-water diagenesis below the seafloor in Upper Jurassic-Lower Cretaceous prodeltaic sandstone and shales, Scotian Basin, Eastern Canada. Mar Pet Geol. 2012;29(1): 175-91.

Pen J, Liu JK, Wang Y, et al. Origin and controlling factors of chlorite coatings - an example from the reservoir of $\mathrm{T}_{3} \mathrm{x}$ Group of the Baojie area, Sichuan Basin, China. Pet Sci. 2009;6(4):376-82.

Shi ZQ, Zeng DY, Xiong ZJ, et al. Sedimentary records of Triassic megamonsoon in Upper Yangtze Area. Bull Mineral Pet Geochem. 2010;29(2):164-72 (in Chinese).

Sun QL, Sun HS, Jia B, et al. Genesis of chlorites and its relationship with high-quality reservoirs in the Xujiahe Formation tight sandstones, western Sichuan depression. Oil Gas Geol. 2012;33(5):751-7 (in Chinese).

Sun ZX, Sun ZL, Yao J, et al. Porosity preservation due to authigenic chlorite coatings in deeply buried Upper Triassic Xujiahe Formation sandstones, Sichuan Basin, western China. J Pet Geol. 2014;37(3):251-68.

Xi KL, Cao YC, Wang YZ, et al. Diagenesis and porositypermeability evolution of low permeability reservoirs: a case study of Jurassic Sangonghe Formation in Block 1, central
Junggar Basin, NW China. Pet Explor De. 2015;42(4):434-43 (in Chinese).

Xiang F, Feng Q, Zhang DY, et al. Further study of chlorite rim in sandstone: evidences from Yanchang Formation in Zhenjing area, Ordos Basin, China. J Chengdu Univ Technol Sci Technol Ed. 2016;43(1):59-67 (in Chinese).

Yao JL, Wang Q, Zhang R, et al. Forming mechanism and their environmental implications of chlorite-coatings in Chang 6 sandstone (Upper Triassic) of Hua-Qing Area, Ordos Basin. Acta Sedimentol Sin. 2011;29(1):72-9 (in Chinese).

Zeng W. Diagenesis and reservoir distribution of Upper Jurassic Series in Zhangqiang Hollow. J Southwest Pet Inst. 1996;18(4):11-6 (in Chinese).

Zhang JZ, Chen SJ, Xiao Y, et al. Characteristics of the Chang 8 tight sandstone reservoirs and their genesis in Huaqing area, Ordos Basin. Oil Gas Geol. 2013;34(5):679-84 (in Chinese).

Zhang X, Lin CM, Chen ZY. Characteristics of chlorite minerals from Upper Triassic Yanchang Formation in the Zhenjing Area, Ordos Basin. Acta Geol Sin. 2011;85(10):1659-71 (in Chinese).

Zhang X, Tian JC, Du BQ, et al. Matching between sandstone tightening and hydrocarbon accumulation of the Xujiahe Formation, Guanyinchang area in southern Sichuan Basin. Oil Gas Geol. 2014;35(2):231-7 (in Chinese).

Zhu HH, Zhong DK, Yao JL, et al. Alkaline diagenesis and its effects on reservoir porosity: a case study of Upper Triassic Chang 7 tight sandstones in Ordos Basin, NW China. Pet Explor Dev. 2015;42(1):51-9 (in Chinese).

Zhu HH, Zhong DK, Zhang YX, et al. Pore types and controlling factors on porosity and permeability of Upper Triassic Xujiahe tight sandstone reservoir in Southern Sichuan Basin. Oil Gas Geol. 2014;35(1):65-76 (in Chinese).

Zhu P, Huang SJ, Li DM, et al. Effect and protection of chlorite on clastic reservoir rocks. J Chengdu Univ Technol Sci Technol Ed. 2004;31(2):153-6 (in Chinese).

Zhu RK, Zou CN, Zhang N, et al. Diagenetic fluids evolution and genetic mechanism of tight sandstone gas reservoirs in Upper Triassic Xujiahe Formation in Sichuan Basin, China. Sci China Ser D. 2009;39(3):327-39 (in Chinese).

Zou CN, Gong YJ, Tao SZ, et al. Geological characteristics and accumulation mechanisms of the "continuous" tight gas reservoirs of the Xu2 Member in the middle-south transition region, Sichuan Basin, China. Pet Sci. 2013;10(2):171-82. 